\title{
System dynamics models for planning long-term integrated municipal solid waste management in Bandung city
}

\author{
N. Rahayu ${ }^{1}$, T. Arai $^{1}$, G. Yudoko ${ }^{2}$ \& H. Morimoto ${ }^{1}$ \\ ${ }^{1}$ Department of Industrial Administration, \\ Tokyo University of Science, Japan \\ ${ }^{2}$ School of Business and Management, \\ Institut Teknologi Bandung, Indonesia
}

\begin{abstract}
Nowadays, the problem of waste has become crucial and challenging all over the world. Although the conventional approach in dealing with the problem has been applied in most developing countries, it has been found inappropriate to manage this complicated problem. Recently, an integrated approach was proposed and has been used for managing the problem. Bandung city is one of the big cities in Indonesia and has such waste problems, which are caused by the increase of waste generation, there being no additional landfill sites for disposing of waste, the low priority on solid waste disposal and lack of stakeholders' awareness. This research aims to propose a simulation model, which is expected to help decision makers (DMs) to plan policies regarding waste management in Bandung city. "Back-casting analysis" and "System Dynamics" are used for taking the integrated approach to create a long-term "Bandung Integrated Municipal Solid Waste Management Plan". The results suggested that waste generation in Bandung city would increase during 2010 and 2035 with the increase of population and economic growth. Several waste treatment facilities would be needed to reduce the amount of waste sent to landfill.

Keywords: back-casting, Bandung, integrated municipal solid waste management, planning, system dynamics.
\end{abstract}




\section{Introduction}

The long-term planning of the management of municipal solid waste (MSW) is exacerbated by a number of factors (Yudoko [1]), such as urbanization, population growth, industrialization to increase growth, improved living standards, and the increased availability of customer products. Future studies are necessary for the planning of MSW management (MSWM) for getting a better understanding of future opportunities and present challenges, for adapting to the most likely future or influencing the future, and for providing reliable and objective predictions to support the decision-makers.

Although "Forecasting" is the quite well-known method for future studies, it has several weaknesses. The predictive record of most forecasting is poor, and even if we could predict the long-term future accurately, we would usually be addressing the wrong question. Then, sometimes the most likely future is not the most desirable, not simply good predictions. A normative planning approach called "Back-casting" emerged during the 1970s, in response to the need for the future study approach that could deal with situations on how to attain specific targets even when forecasts demonstrated that such targets could not be met.

Bandung city is one of the big cities in Indonesia and no additional landfill sites for disposal of waste is the most crucial problem for the MSWM in the city. Additionally, low priority on solid waste disposal and lack of stakeholders' awareness of the problem make it even worse. It was estimated [2-4], that at most only around $60 \%-70 \%$ of the entire waste generated in 2011 could be transported to final disposal sites. The sources and volumes of waste can be seen in Table 1.

Table 1: $\quad$ Source of waste in Bandung city (2011).

\begin{tabular}{|c|l|r|r|r|}
\hline \multirow{2}{*}{ No. } & Source or Waste Generator & \multicolumn{2}{|c|}{ Volume } & Carried out \\
\cline { 3 - 4 } & & $\mathrm{m}^{3} /$ day & ton/day & $\begin{array}{c}\text { by PDK } \\
\left(\mathrm{m}^{3} / \text { day }\right)\end{array}$ \\
\hline 1. & Residential & $4,951.98$ & $1,188.48$ & 3,038 \\
\hline 2. & Market & 618.50 & 148.44 & 459 \\
\hline 3. & Commercial & 302.80 & 72.67 & 168 \\
\hline 4. & Street & 465.1 & 111.65 & 295 \\
\hline 5. & Industrial & 798.50 & 191.64 & 366 \\
\hline 6. & Non-commercial/public facilities & 363.60 & 87.26 & 174 \\
\hline \multicolumn{2}{|c|}{ Total } & $7,500.58$ & $1,800.14$ & 4,500 \\
\hline
\end{tabular}

*Source: PDK 2011, Bandung city statistics index.

"Bandung Waste Management” is managed by PD Kebersihan (the municipal cleaning company) which is one implementing unit under the government of Bandung city $[4,5]$. Bandung City Waste Management is still using a simple collection processes and discarding the collected waste into landfill. Further processing is done on the spot of final disposal by composting and also recycling informally. 
There is no source-separation of waste at various generation points like households, institutions, and commercial enterprises. The current MSW management system in Bandung city relies on the existence of landfill. So far, the existing landfill is not adequately prepared and not professionally operated. On the other hand, the consciousness on the part of the surrounding communities of their right to enjoy better environmental quality in their lives is ever increasing. This problem is made worse by the incapability of the site managers in coordinating the waste pickers who compete for handling the waste.

There are no treatment facilities from household level until temporary waste shelter for the municipal waste. Societies manage their waste by burning or throw it into river. Reasons spotted are lack of motivation and knowledge of the citizen, financial restraint in the PDK, absence of private sector participation, etc. Even technologies such as composting which needs small capital investment is not practiced well $[4,5]$. Until these days, PDK still focus on daily operational management and not yet emphasis on long-term integrated MSWM planning.

The fact that the implementation of waste management in Bandung city still has not produced a good result as expected shows the new approach is required in order to produce a better way to fix the waste problem. Focusing in development some scenarios to be applied in Bandung city and selecting one best strategy to follow might be an important step to eliminate the gap of expected result with the real outcome, and in turn, to increase the effectiveness and efficiency of the integrated MSWM policy.

Waste management is a complex process that involves inter-connected issues such as waste generation, waste processing, landfill capacity, environmental impacts and financial expenditure; it becomes increasingly necessary to understand the dynamic nature of their interactions [6, 7]. In this research System Dynamics is used to address some of these issues by fitting a model framework for the integrated MSWM in Bandung city.

\section{Methodology}

This research proposed back-casting analysis to be used as the alternative to develop long-term Bandung IMSWM. Back-casting also describe as "backwards-looking analysis", is a form of scenario generation that trying to predict the possible path of the desired alternative by Robinson [8]. Back-casting was chosen due to its advantages in dealing with future uncertainties, and more flexible and responsible policy agenda. In this research, System Dynamics is needed to evaluate the back-casting scenarios of IMSWM in Bandung city.

\subsection{Back-casting scenarios}

In this research, the targets need to be achieved was reducing waste sent to landfill site from waste generated in 2035. The year of 2010 was set as the base year where all generated waste sent to landfill site for final disposal without any pre-treatment measure. In the target year 2035, beside waste reduction at source, one Waste-to-Energy plant will be located within Bandung city to treat generated 


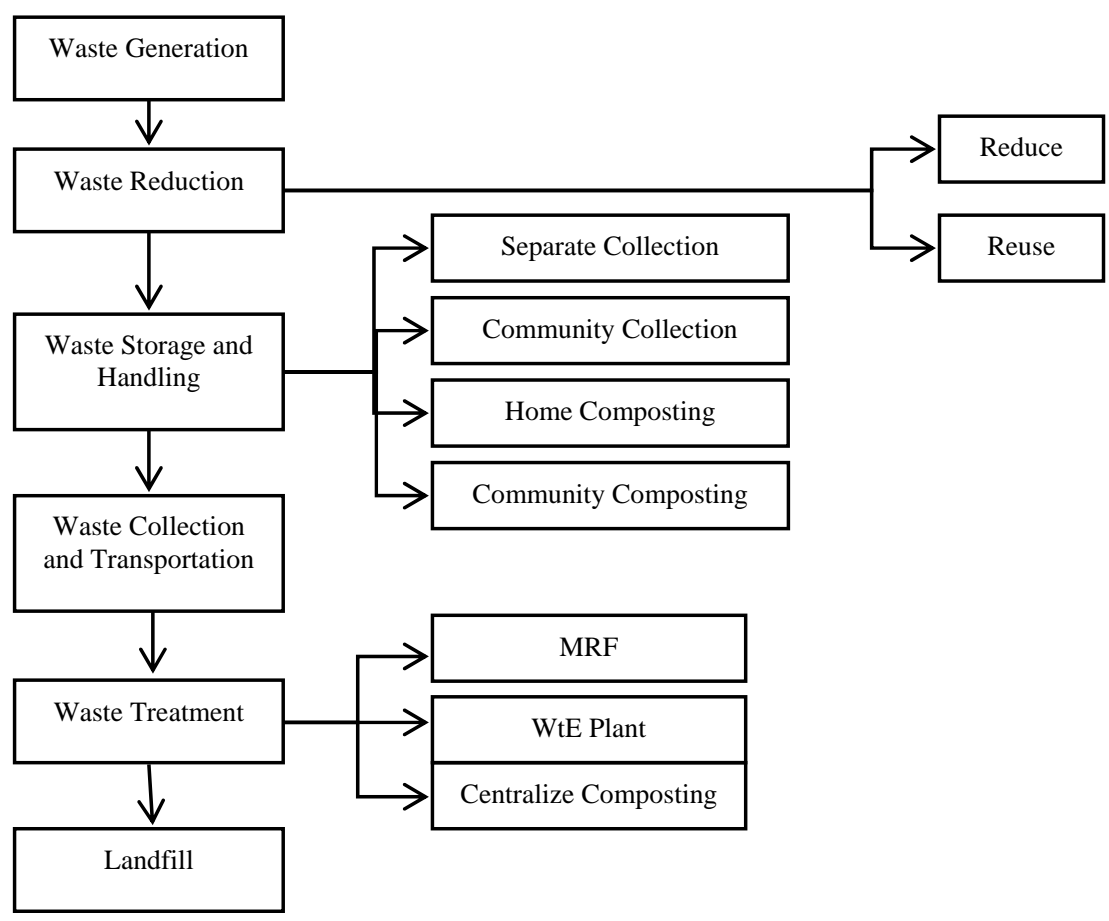

Figure 1: $\quad$ The proposed IMSWM in Bandung city.

waste before sending to landfill site for final disposal. This research proposed three different scenarios to deal with waste management problem in Bandung city, the scenarios take time horizon for 25 years (2010-2035) as follows:

1. 2035: Business As Usual (BAU) Scenario

The BAU scenario is a reference scenario showing the continuation of present trends in waste management, moderately by likely changes in processing and technology. The BAU scenario assumed that no significant policy changes and no major technical changes would take place in the waste treatment sector. Only technical innovations were assumed that can be expected to happen from today's point of view.

2. Zero waste sent to landfill by 2035

This scenario is a back-cast scenario constant with the IMSWM criteria, not only based on an analysis of current driving forces and societal trends, but also using existing knowledge and the literatures on waste disposal alternatives and future disposal system. The zero waste scenario described a path towards sustainable waste management that met the identified criteria in 2035. 


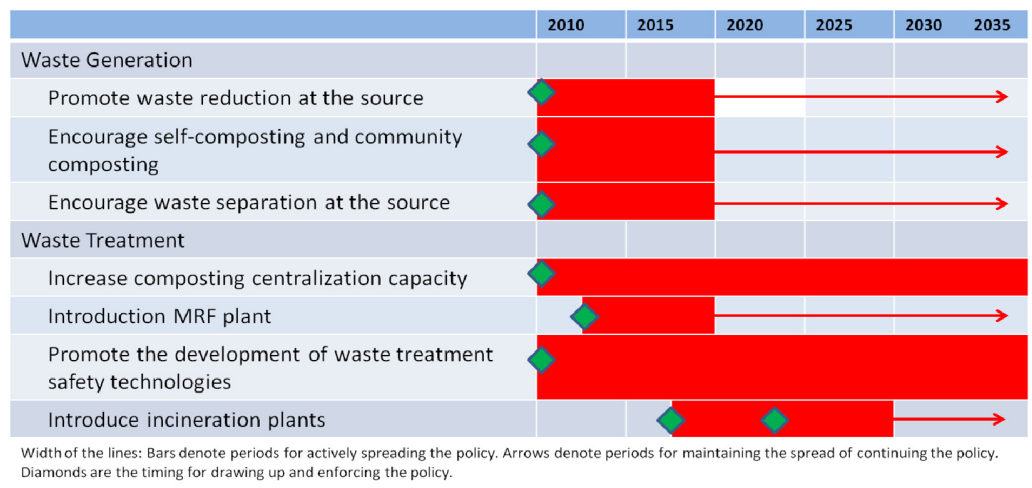

Figure 2: Gantt chart of alternatives towards zero waste sent to landfill by 2035.

3. $80 \%$ waste reduction sent to landfill by 2035

With $80 \%$ waste reduction we could observe the waste generation impacts if we apply the same time horizon but weaken the treatment goals and decrease the intensity of policy measures that change the waste management behavior of population and businesses.

\begin{tabular}{|c|c|c|c|c|c|}
\hline & 2010 & 2015 & 2020 & 2025 & 2030 \\
\hline \multicolumn{6}{|l|}{ Waste Generation } \\
\hline \multicolumn{6}{|l|}{ Promote waste reduction at the source } \\
\hline \multicolumn{6}{|l|}{$\begin{array}{l}\text { Encourage self-composting and community } \\
\text { composting }\end{array}$} \\
\hline \multicolumn{6}{|l|}{ Encourage waste separation at the source } \\
\hline \multicolumn{6}{|l|}{ Waste Treatment } \\
\hline \multicolumn{6}{|l|}{ Increase composting centralization capacity } \\
\hline \multicolumn{6}{|l|}{ Introduction MRF plant } \\
\hline \multicolumn{6}{|l|}{$\begin{array}{l}\text { Promote the development of waste treatment } \\
\text { safety technologies }\end{array}$} \\
\hline Introduce incineration plants & & & 4 & & $\rightarrow$ \\
\hline
\end{tabular}

Figure 3: Gantt chart of alternatives towards $80 \%$ waste reduction sent to landfill by 2035 .

\subsection{Model description and simulation}

The model developed here applies a System Dynamics by using STELLA ${ }^{\circledR}$. It is expected to help planners and decision makers in assessment of waste management options. In solid waste management field, System Dynamics is applied in planning for developing countries in India by Sudhir et al. [9], prediction of solid waste generation [7, 10], strategic planning of construction and demolition waste management by Hao et al. [11], and evaluating the 
Table 2: $\quad$ Scenarios’ assumption.

\begin{tabular}{|c|c|c|c|}
\hline Scenario & Action & Waste type & Assumption \\
\hline BaU Scenario & Conventional & Comingle & All waste sent to landfill \\
\hline \multirow{5}{*}{$\begin{array}{l}\text { * Zero waste } \\
\text { sent to } \\
\text { landfill } \\
\text { scenario }\end{array}$} & $\begin{array}{l}\text { Home and } \\
\text { community } \\
\text { separation }\end{array}$ & $\begin{array}{c}\text { Product (paper and } \\
\text { plastic); packaging } \\
\text { (paper, plastic, glass, } \\
\text { metal) }\end{array}$ & $100 \%$ separated waste \\
\hline & $\begin{array}{l}\text { Home and } \\
\text { community } \\
\text { composting }\end{array}$ & $\begin{array}{l}\text { Product (food, fruit, } \\
\text { vegetable) }\end{array}$ & $5 \%$ composting activity \\
\hline & \multirow{3}{*}{$\mathrm{WtE}$} & \multirow{3}{*}{ Separated waste } & $\begin{array}{l}\text { After source reduction, } \\
\text { recyclable materials are } \\
\text { collected and sent for } \\
\text { incineration treatment. }\end{array}$ \\
\hline & & & $\begin{array}{l}\text { 30\% waste burned in } \\
\text { incinerator. } *\end{array}$ \\
\hline & & & $\begin{array}{l}27 \% \text { waste burned in } \\
\text { incinerator. }{ }^{* *}\end{array}$ \\
\hline \multirow[t]{6}{*}{$\begin{array}{l}\qquad * 80 \% \\
\text { waste } \\
\text { reduction sent } \\
\text { to landfill } \\
\text { scenario }\end{array}$} & \multirow{3}{*}{$\begin{array}{l}\text { MRF Private } \\
\text { business (from } \\
\text { waste pickers) }\end{array}$} & \multirow{3}{*}{$\begin{array}{l}\text { Product (plastic, } \\
\text { paper, glass, metal); } \\
\text { packaging (plastic, } \\
\text { paper, glass, metal) }\end{array}$} & $\begin{array}{l}\text { After source reduction, } \\
\text { recyclable materials are } \\
\text { collected and sent for MRF } \\
\text { treatment and recycle. }\end{array}$ \\
\hline & & & $16.6 \%$ waste recycled.* \\
\hline & & & $8 \%$ waste recycled.** \\
\hline & \multirow[t]{3}{*}{$\begin{array}{c}\text { Central } \\
\text { composting }\end{array}$} & \multirow[t]{3}{*}{$\begin{array}{l}\text { Product (food, fruit, } \\
\text { vegetable) }\end{array}$} & $\begin{array}{l}\text { After source reduction, } \\
\text { recyclable materials are } \\
\text { collected and sent for } \\
\text { composting treatment and } \\
\text { recycle. }\end{array}$ \\
\hline & & & $19.4 \%$ waste composted. $*$ \\
\hline & & & $19.4 \%$ waste composted. $* *$ \\
\hline
\end{tabular}

interaction of solid waste management system components by Kollikkathara et al. [6].

The utility of the model is demonstrated by fitting its framework for examining municipal solid waste generation and it's processing in Bandung. The figures below shows STELLA flow diagrams of the System Dynamics model used to analyze the IMSWM of Bandung city. 


\subsubsection{IMSWM model}

In Figure 4, total waste was accumulated from five different sectors: population, weekend population, markets, schools and offices, and public facilities. Waste generation is assumed to increase due to population and economic growth. In this model, type of waste were divided into organic and inorganic waste. Organic waste consisted of foods, vegetables and yard waste, while inorganic waste consisted of paper, plastic, metal, glass, textile and rubber.

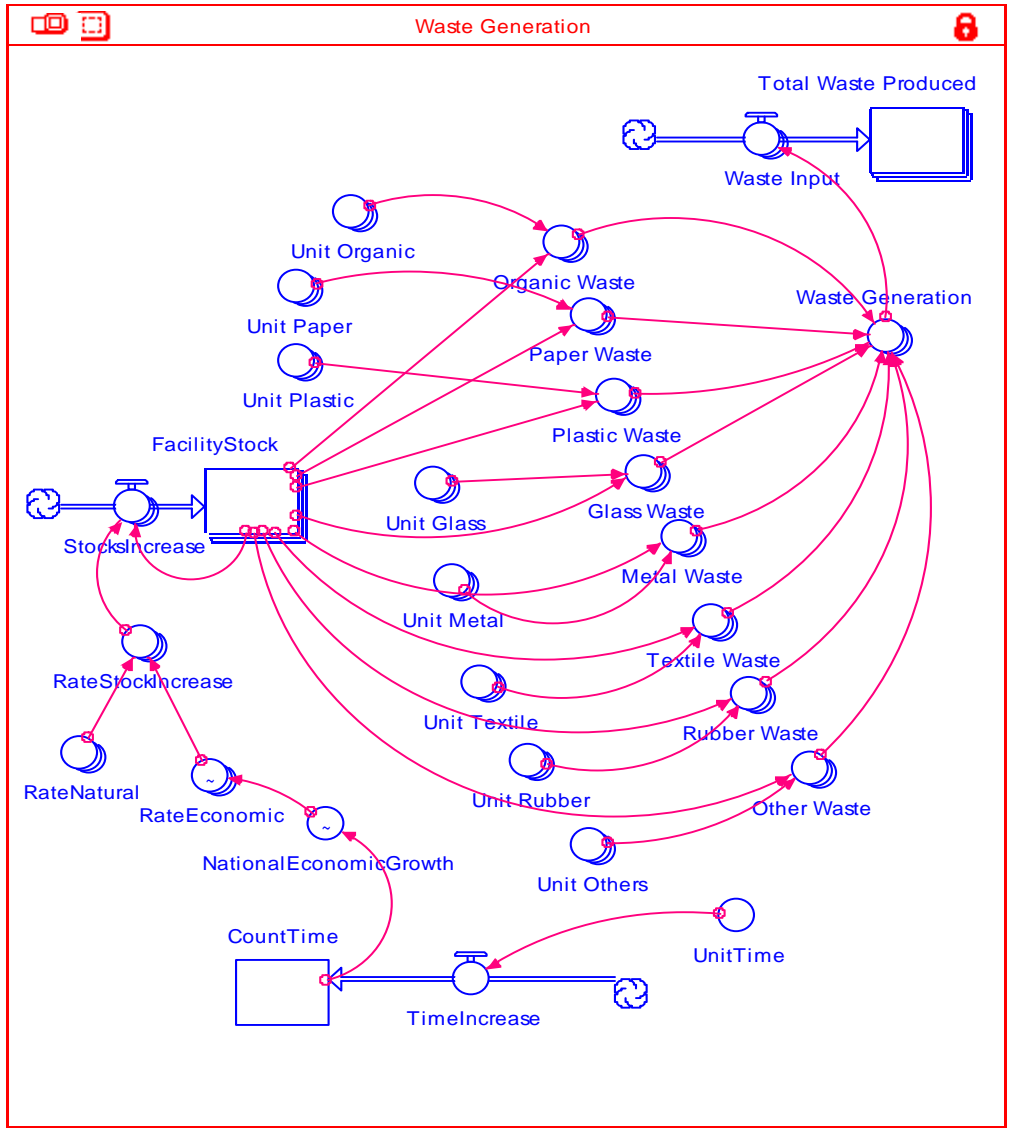

Figure 4: Waste generation sub-system.

Waste collection sub-system contained of number of trucks, number of trip, collection capacity, and financial sector related to waste collection activity. Figure 5 shows the waste collection system in Bandung city, it began from waste generation until total waste collected. Every sub-system in this model was interconnected by STELLA symbol ghost, a means of tidy presentation of interconnections. For example, dotted total waste generation in Figure 5 is the 


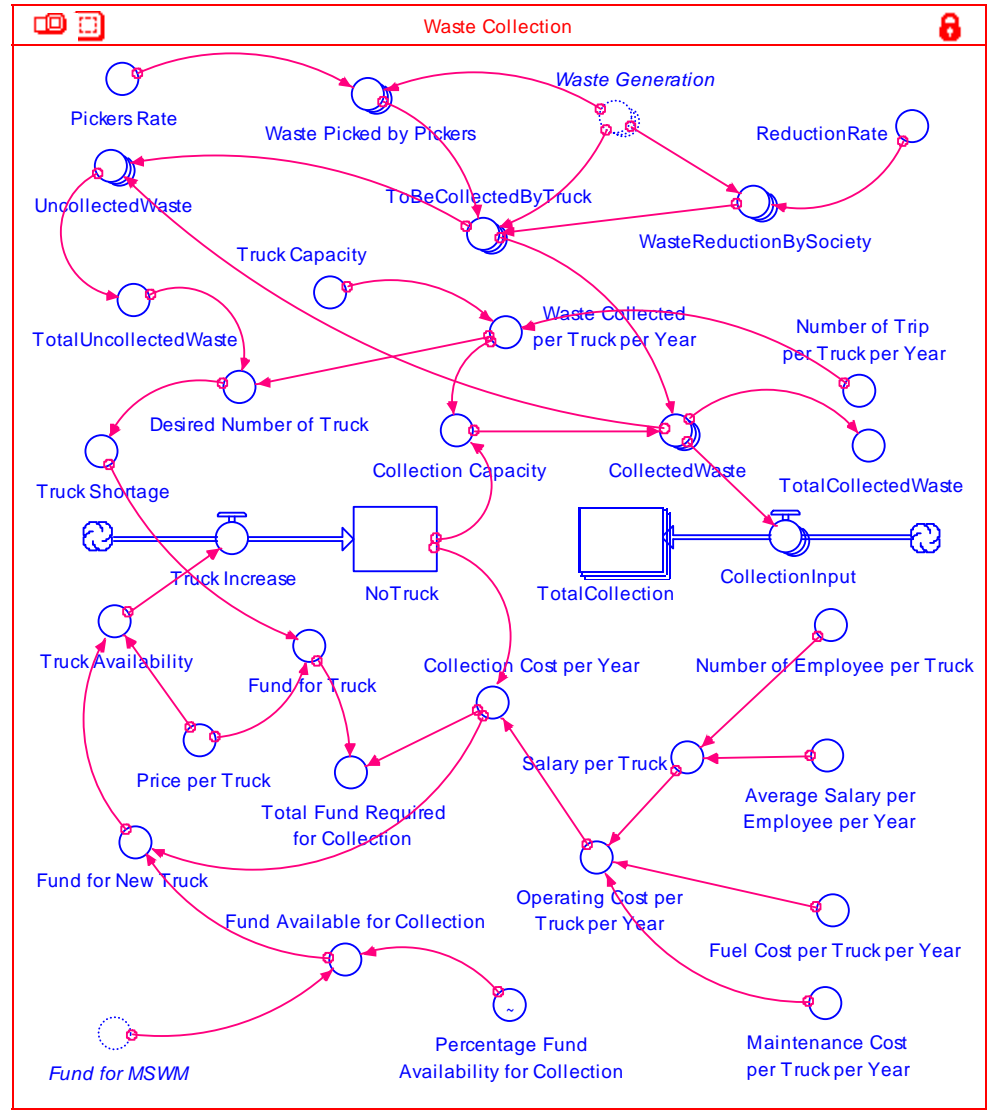

Figure 5: $\quad$ Waste collection sub-system.

ghost of waste generation in Figure 4, and it shows the connection of total waste generation that needs to be treated.

Number of truck and budget allocation for waste collection were the feedback for collection efficiency. If there is more budget allocation for truck availability, there would be more waste could be collected. On the other hand, more waste collected means more waste to be treated in the next sub-systems.

Figure 6 shows the composting sub-system as the action of waste treatment in the proposed model. In this sub-system, composting site capacity determined how much compostable waste could be composted. If the composting capacity is lower than compostable waste, then the rest would be sent to incineration site to be burned. 


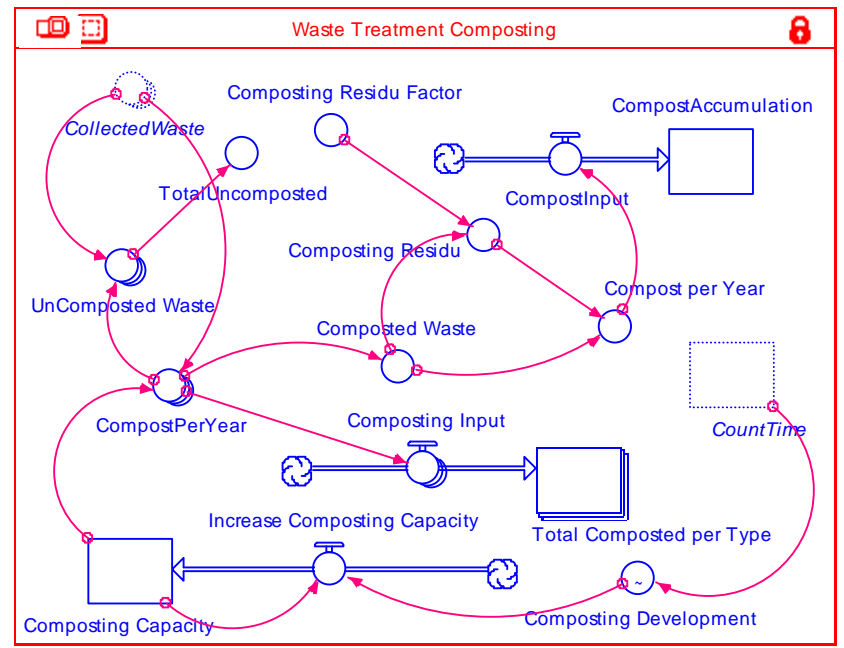

Figure 6: Waste composting sub-system.

Figure 7 shows the material recycling facility. In this sub-system, the potential of recyclable waste would be processed into recycle products. The amount of recycle products determined by MRF capacity. Figure 8 shows the incineration facility. In this sub-system, the amount of waste that could not be treated by composting and MRF would be burned in incinerator.

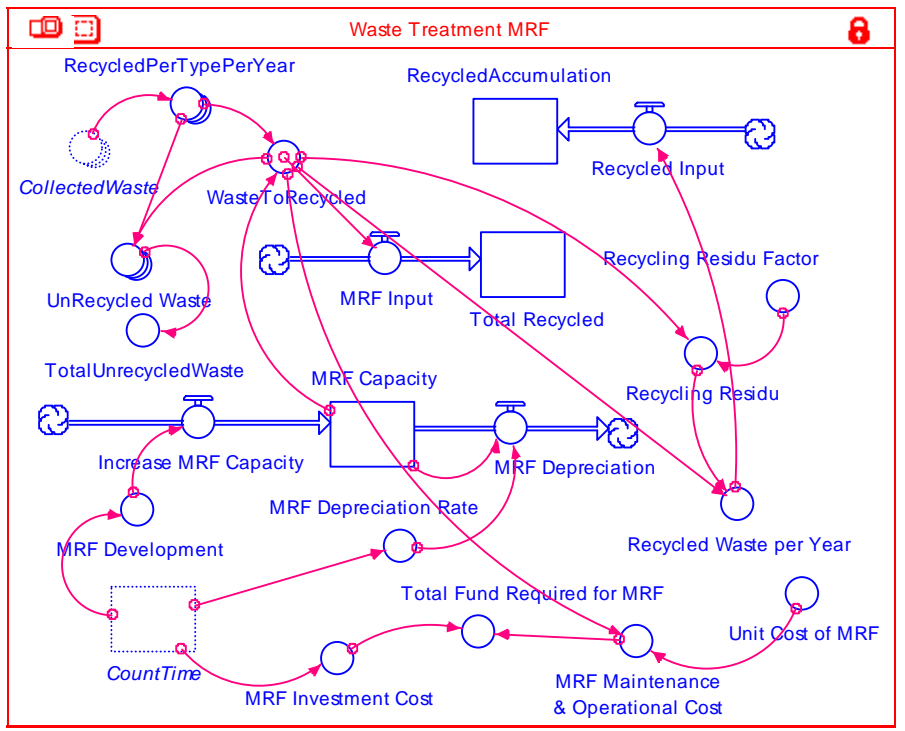

Figure 7: Material recycling facility sub-system. 


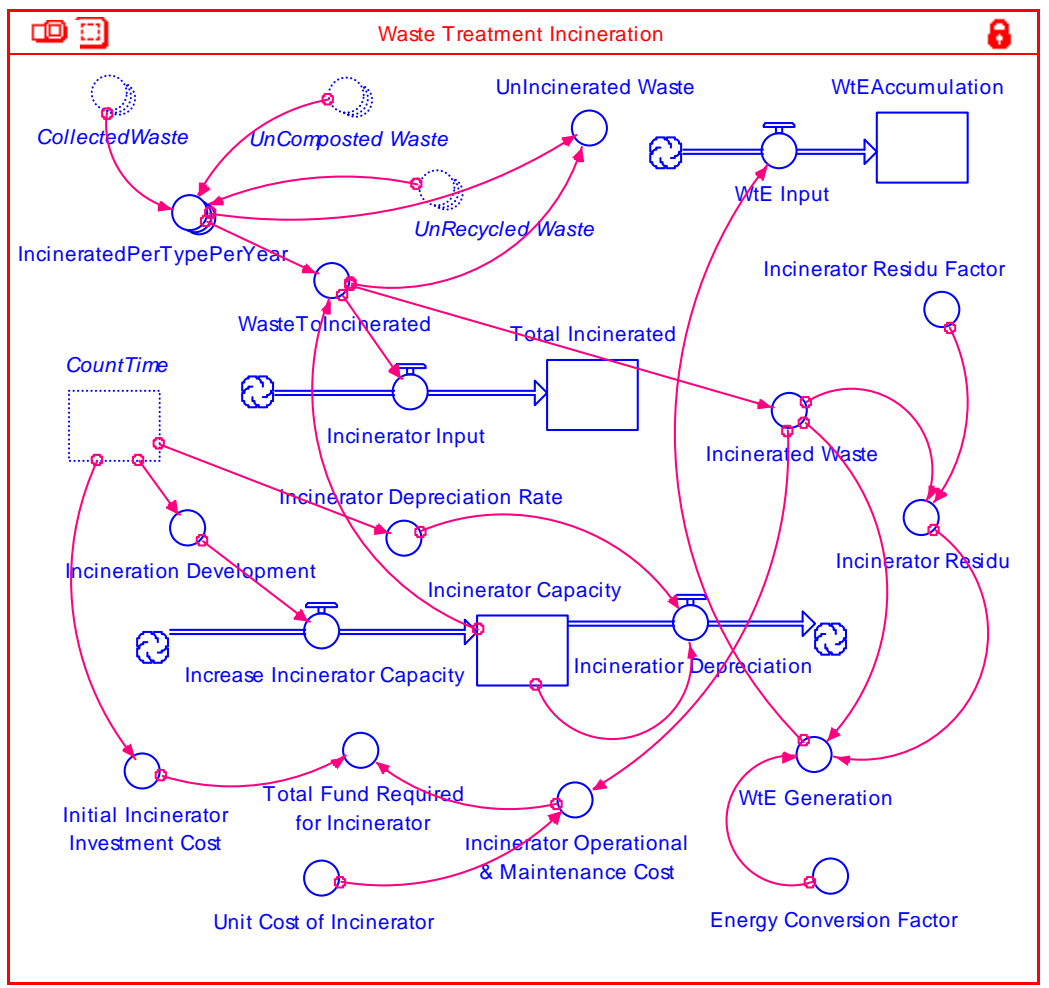

Figure 8: Waste incineration sub-system.

The landfill sub-system can be seen in Figure 9. All waste which could not be treated and the residue from each treatment facility would be sent to landfill as the last place for disposing waste. This sub-system shows the landfill capacity and the rate filling of landfill, that indicate how long the landfill cou dbe operated. If there is no waste treatment action to reduce the amount of waste sent to landfill, it assumed that landfill would be closed quickly due to waste accumulation in landfill site. Waste sent to landfill would be compacted. In this model, we used compaction factor from The US Environmental Protection Agency (USEPA) of $118.65 \mathrm{~kg} / \mathrm{m}^{3}$ (200 lbs/yd $\mathrm{d}^{3}$ ) for mixed waste in USEPA [12].

The financial sub-system can be seen in Figure 10. This sub-system considered not only the operational and maintenance costs for landfill, MRF, and incinerator plants, but also energy generated from waste, composts and recycle products selling.

Energy generated would be electricity, and it assumed could be sold Rp.1000/kWh. On the other side, compost produced from organic waste could be sold around Rp.200/kg to Asosiasi Kelompok UPPKS (Association of Business Group Revenue for Increasing Family Welfare), or higher price around Rp.500Rp.600/kg to markets or private sectors, while recycled products such as pellets could be sold at around Rp.1000/kg. 


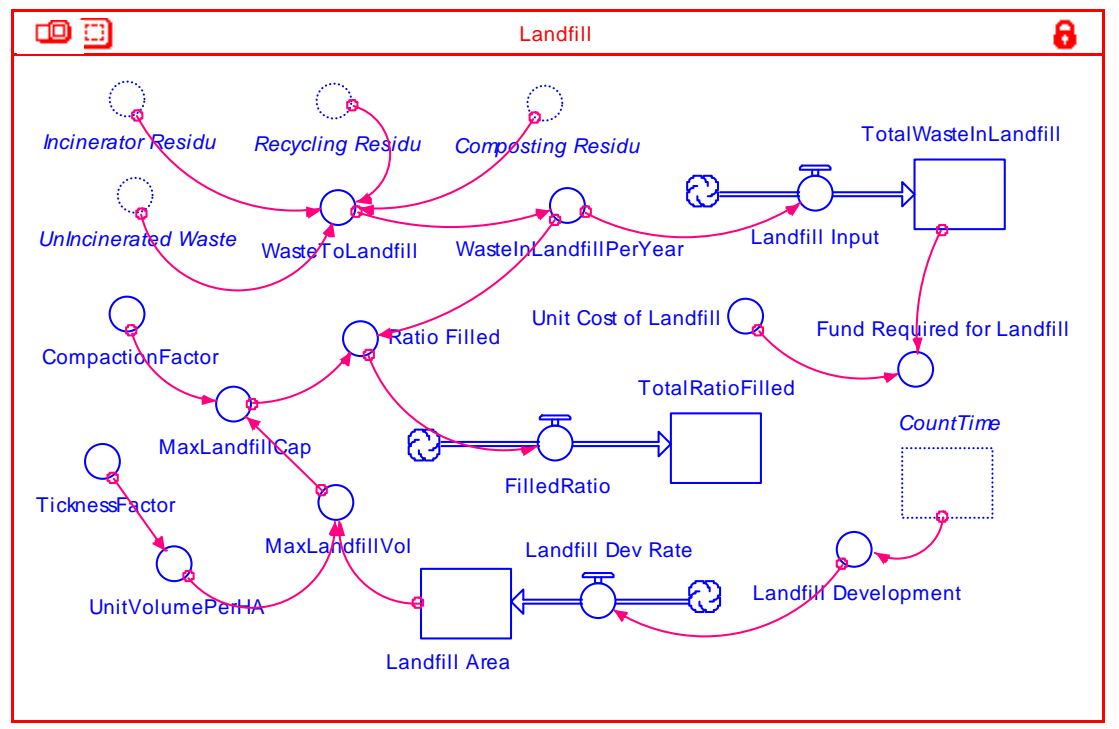

Figure 9: Landfill sub-system.

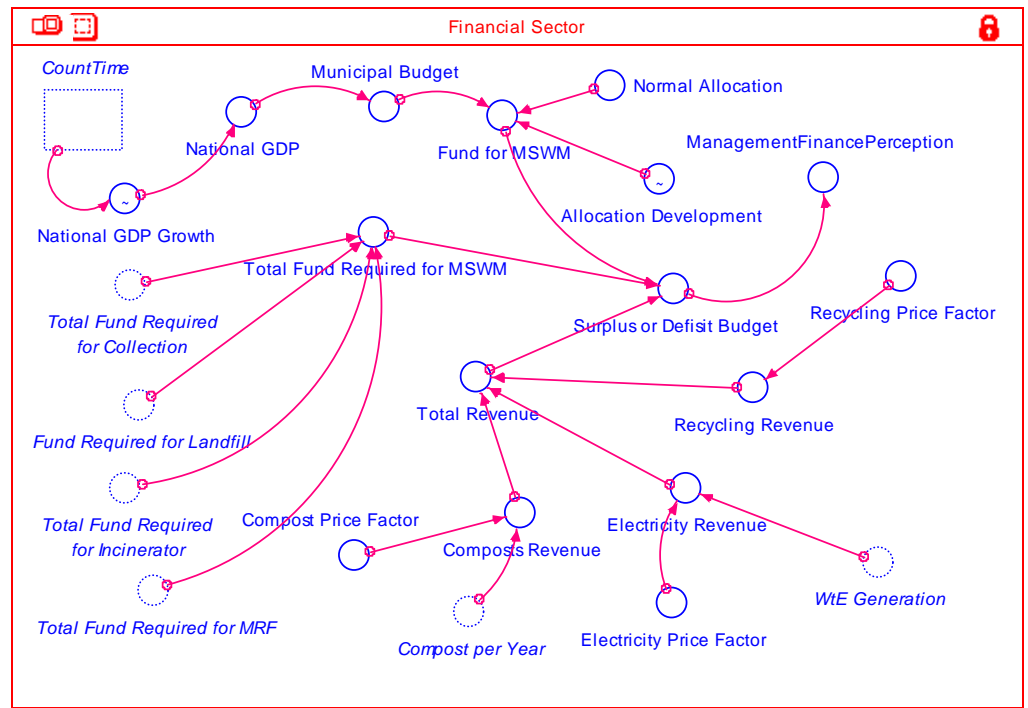

Figure 10: Financial sector sub-system.

Surplus or deficit budget in this model was the total amount of waste product selling revenue and fund of MSWM from municipality after reduced by waste treatment costs. If they have deficit budget, it would affect management perception to increased fund allocation either by increasing waste retribution or by cooperating with private sector in handling waste processing. In the case of 
increasing retribution, it assumed to affect public concern (evaluated in shortterm model) for reducing and handling their waste from the source, and it would decrease the amount of waste generation and waste to be collected by PDK.

\section{Results and scenario analysis}

In BAU scenario, waste accumulated at landfill was around 18 million tonnes by 2035, while in zero waste scenario and in $80 \%$ waste reduction scenario total waste accumulated was around 6 million tonnes and 9 million tonnes respectively. Without any waste treatment, only depended on small amount of composting site capacity, it was estimated that about 865,856.84 tonnes waste would sent to landfill by the year 2035 in BAU scenario. While in zero waste and $80 \%$ waste reduction scenario, which proposed three new waste treatment facility sites, waste could be reduced, and only $7 \%$ and $17.8 \%$ sent to landfill in 2035.

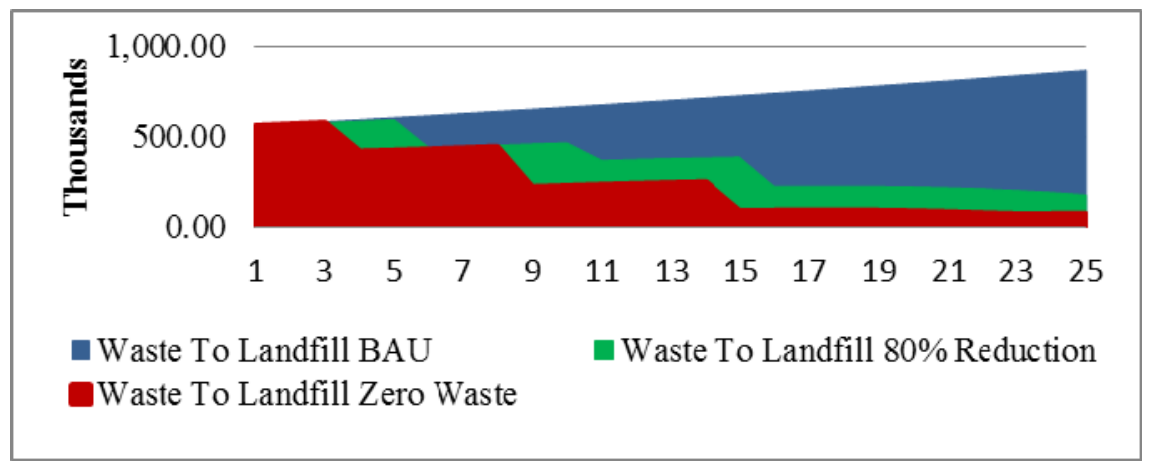

Figure 11: Comparison of waste sent to landfill for time horizon 25 years.

Even though by installing new waste treatment facilities to reduce waste sent to landfill, it was also necessary to reduce waste from the source. By running short-term model, it was estimated that up to $6.5 \%$ of total recyclable waste could be reduced by society. 50\% reduction of paper and plastic, also $5 \%$ composting were chosen as the options in waste handling at source.

Figure 12 shows the comparison of composting, recycling and incinerator products from waste between proposed scenarios. Total compost produced by 2035 in BAU scenario, zero waste scenario and 80\% waste reduction scenario were 1,654,937.15 tonnes; 3,410,184.29 tonnes; and also 3,410,184.29 tonnes respectively.

On the other side, recycling products in zero waste scenario were higher than the other scenarios which was 3,638,417.96 tonnes in 2035 compare to 0 ton in BAU scenario and 1,456,350 tonnes in $80 \%$ waste reduction scenario. Total waste incinerated in BAU scenario was 0 ton due to no incineration plant, while in zero waste scenario was 5,891,354.26 tonnes waste were incinerated by 2035 
and 5,110,000 tonnes waste in $80 \%$ waste reduction scenario. It shows that massburn incinerator could destroy the most waste in Bandung city.

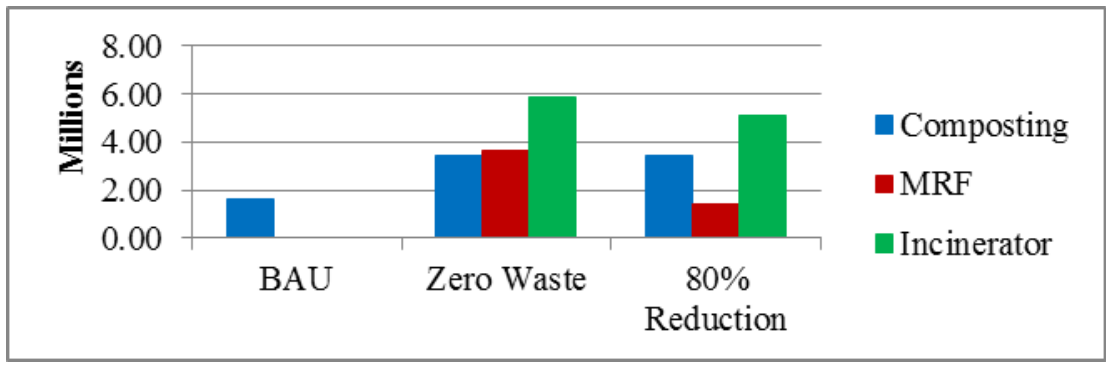

Figure 12: Comparison of MSW disposal and treatment facilities for time horizon 25 years.

Figure 13 shows the potential of electricity generated from waste. In zero waste scenario, electricity generated was higher than in $80 \%$ waste reduction, which was 53,022.19 MWh compare to 45,990 MWh by the year 2035, while 0 MWh electricity generated from BAU scenario.

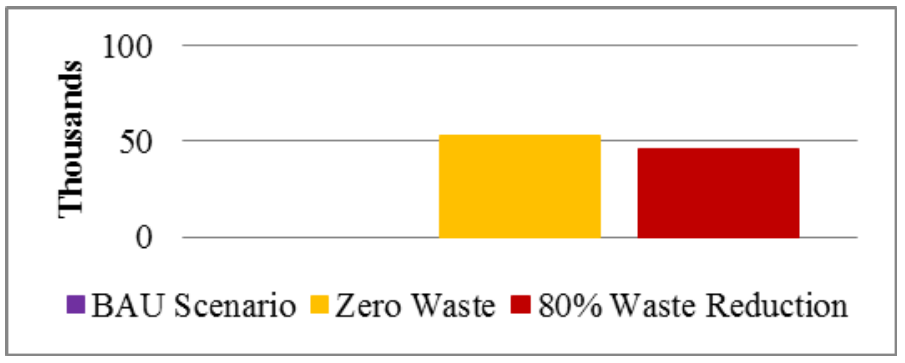

Figure 13: Comparison of electricity generated projection for time horizon 25 years (Mwh).

Figure 14 shows landfill filling rate from three different scenarios. In BAU scenario without any significant prevention, landfill would be full in 2019. As already mention above, Sarimukti landfill not only used by Bandung city, but also shared by Cimahi city and Kabupaten Bandung. West Java government predicted this landfill site would be full and closed in 2018. In this research, landfill filling rate determined by landfill construction which is estimated to have 5 layers. Each layer consisted of $80 \%$ of waste and $20 \%$ of soil, with compaction factor $118.65 \mathrm{~kg} / \mathrm{m}^{3}$.

In back-cast scenarios, landfill would have longer life time. As in zero waste scenario, it was estimated that $66.28 \%$ of landfill capacity would full by the year 2035. While $95.18 \%$ of landfill capacity would full by the year 2035 in $80 \%$ waste reduction scenario. Waste treatments before waste sent to landfill have important role in reducing the amount of waste sent to landfill. 


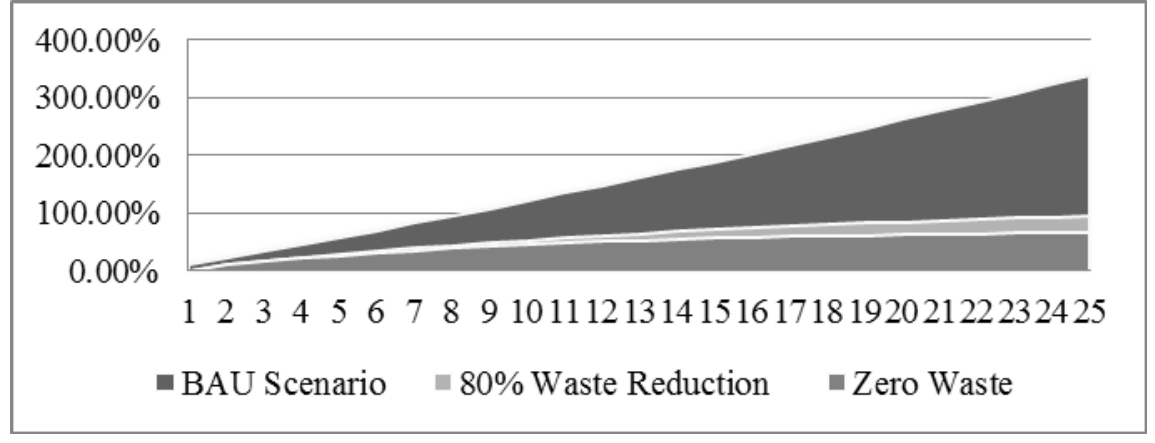

Figure 14: Comparison of landfill filling rate projection for time horizon 25 years.

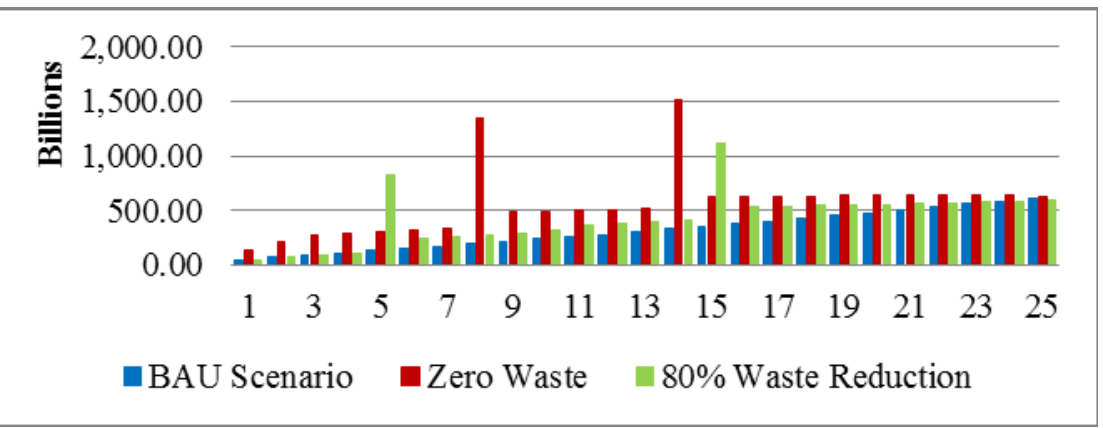

Figure 15: Comparison of total cost from different facilities.

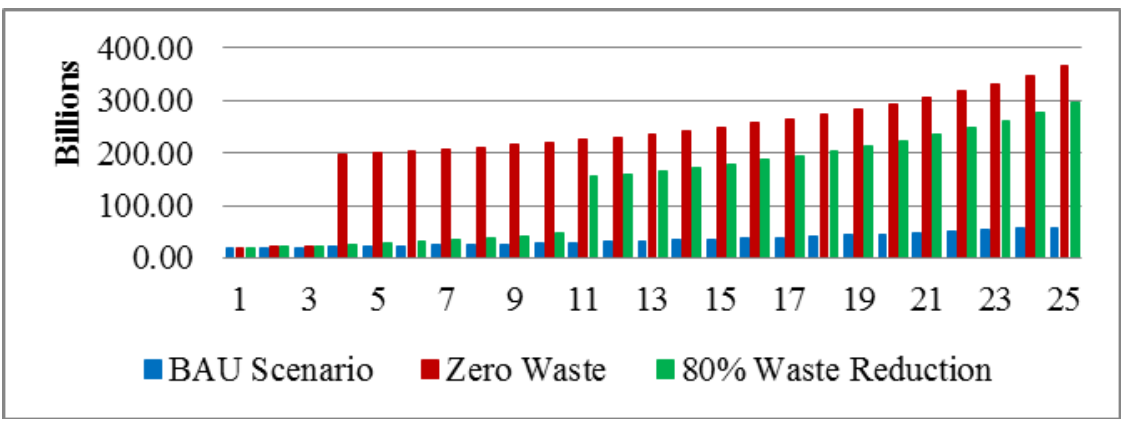

Figure 16: Comparison of total revenue from different facilities.

In order to reduce waste sent to landfill, Bandung city needs more budget for building new treatment facilities. The more capacity and more modern the facility, the more money needed. This condition would trigger pro and contra between stakeholders weather these proposed facilities would built or not. 
Total revenue in zero waste scenario was higher than total revenue in other scenarios due to optimum selling from three kind of waste products. Both backcast scenarios generated total revenue Rp.364.86 billion and 295.15 billion for zero waste scenario and 80\% waste reduction scenario respectively in 2035 . While BAU scenario revenue only generated from compost selling, back-cast scenarios generated revenue from compost, recycling and energy selling. Waste reduction by using waste treatment facility not only could reduce the amount of waste sent to landfill, but also could produce revenue from waste products.

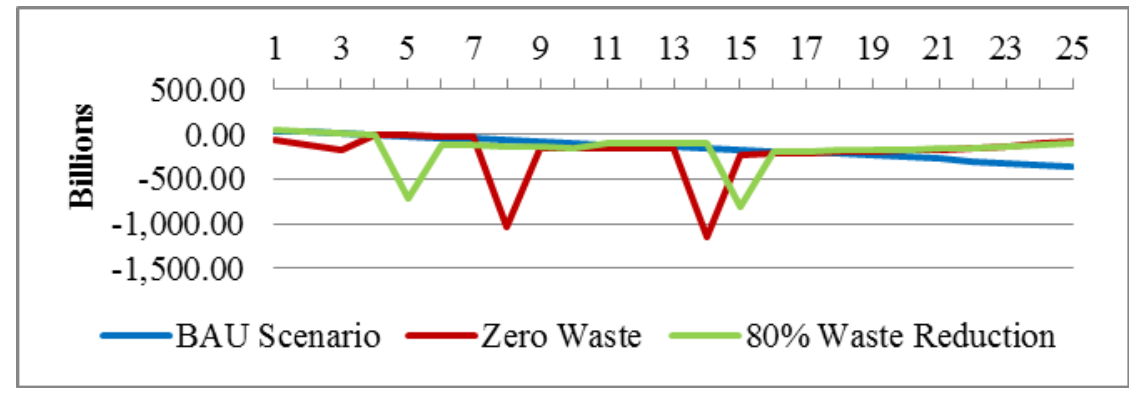

Figure 17: Comparison of surplus or deficit budget for MSW in Bandung city.

All scenarios have deficit budget even after selling waste products due to costs for facilities' installment and operational. Figure 17 shows that even though back-cast scenarios have deficit budget in 2035, it still estimated to be lower than BAU scenario's deficit budget. In 2035, zero waste scenario and 80\% waste reduction scenario would have deficit budget around Rp. 80.19 billion and Rp. 107.97 billion respectively, while BAU scenario has Rp. 367.48 billion.

\section{Conclusion}

This research has proposed a system dynamics model for the study of the potential and systemic consequences of various structural and policy alternatives for an IMSWM system. The results of the study indicate that the waste generation in Bandung city would increase during 2010-2035 with the increased of population at annual rate $1.15 \%$. There was increased in the rate of collection, composting and recycling, while MSW disposed in landfill would decrease in 2035 due to the increasing rate of MSW treated.

Although waste reduction vary according to the scenario, both back-cast scenarios, zero waste and $80 \%$ waste reduction, shared many technology options. These options involved 'no-regret' investments, which reduce the amount of waste sent to landfill and were profitable. The electrical energy generation potential from mass-burn incinerator was increase from 2010 to 2035. The projection revenue produced from different facilities also would increase and this revenue affect positively the budget required for MSW disposal and treatment facilities by covering the costs required for these facilities in 2035 . 
In addition, modifications an extension of the model will focus on its simulation capability to support explorative learning, qualitatively and quantitatively, about the dynamics of IMSWM especially in developing countries.

\section{References}

[1] Yudoko, G., Integrated municipal solid waste planning and management (IMSWPM) in developing countries: a conceptual framework. Journal Management Technology MBA ITB, Vol. 5, pp. 23-35, 2004.

[2] Damanhuri, E., Handoko, W. and Padmi, T., Municipal solid waste management in Indonesia (Chapter 7). Municipal Solid Waste Management in Asia and the Pacific Islands for Society of Solid Waste Management Expert in Asia and Pasific Islands (SWAPI). Institut Teknologi Bandung: Bandung, pp. 95-112, 2010.

[3] Surakusumah, Wahyu. Permasalahan sampah Kota Bandung dan alternatif solusinya. Undergraduate Thesis. Universitas Pendidikan Indonesia: Bandung, 2008.

[4] Perusahaan Daerah Kebersihan (PDK) Kota Bandung. (2011): Unpublished data, Bandung, West Java.

[5] Damanhuri, E., Wahyu, I. M., Ramang, R. and Padmi, T., Evaluation of municipal solid waste flow in the Bandung Metropolitan Area, Indonesia. Journal Master Cycle Waste Management, 11, pp. 270-276, 2009.

[6] Kollikkathara, N., Feng, H. and Yu, D. A system dynamic modeling approach for evaluating municipal solid waste generation, landfill capacity and related cost management issues. Waste Management, 30, pp. 2194-2203, 2010.

[7] Dyson, B. and Chang, N.B., Forecasting municipal solid waste generation in a fast-growing urban region with system dynamics modeling. Waste Management, 25, pp. 669-679, 2005.

[8] Robinson, J.B. Energy Backcasting: A Proposed Method of Policy Analysis, Energy Policy, pp. 337-344, 1982.

[9] Sudhir, V., Srinivasan, G. and Muraleedharan, V.R. Planning for sustainable solid waste management in urban India. System Dynamics Review, 13 (3), pp. 223-246, 1997.

[10] Sufian, M.A., and Bala, B.K. Modeling of urban solid waste management system: the case of Dhaka city. Waste Management, 27, pp. 858-868, 2007.

[11] Hao, J.L., Hills, M.J., and Huang, T., A simulation model using system dynamic method for construction and demolition waste management in Hong Kong, Construction Innovation: Information, Process, Management, 7, 7-21, 2007.

[12] USEPA. Waste Prevention, Recycling and Composting Options: lesson from 30 communities. http://nepis.epa.gov/. Solid Waste and Emergency Response. Washington DC, USA, 1994. 